\title{
Interactive Impact of Irrigation and Fertigation Level on Growth and Yield Attributes of Cucumber under Naturally Ventilated Polyhouse
}

\author{
Dattatray P. Pawar ${ }^{1 *}$, S. R. Bhakar ${ }^{1}$, S. S. Lakhawat ${ }^{2}$, Mahesh Kothari ${ }^{1}$ and Vinay Patil ${ }^{1}$ \\ ${ }^{1}$ Department of Soil and Water Engineering, C.T.A.E, MPUAT, Udaipur-313001, \\ Rajasthan, India \\ ${ }^{2}$ Department of horticulture, RCA, MPUAT, Udaipur-313001, Rajasthan, India \\ *Corresponding author
}

\begin{tabular}{|l|}
\hline Ke y w o r d s \\
$\begin{array}{l}\text { Naturally ventilated } \\
\text { polyhouse, cucumber, } \\
\text { irrigation and fertigation } \\
\text { level, growth, yield } \\
\text { attributes }\end{array}$ \\
\hline Article Info \\
\hline $\begin{array}{l}\text { Accepted: } \\
\text { 20 May 2018 } \\
\text { Available Online: } \\
\text { 10 June } 2018\end{array}$ \\
\hline
\end{tabular}

\section{A B S T R A C T}

The field experimental study was carried out under naturally ventilated polyhouse during winter season at plasticulture farm of CTAE, Udaipur to study the influence of irrigation and fertigation level on growth \& yield attributes of cucumber. The experiment consisted of 9 treatment combination with 3 replication in randomized block design. The treatments include 3 irrigation levels viz. $100 \%, 80 \%$ and $60 \%$ ET through drip and 3 levels of fertilizer application viz. $125 \%, 100 \%, 75 \%$ RDF of N,P,K through fertigation. The effects of different treatments recorded the significant effect on growth and yield attributes of cucumber. Maximum average plant height $(399.27 \mathrm{~cm}$ ), days to $50 \%$ flowering (30.67), days to first harvest $(42.67)$, average length of fruit $(15.92 \mathrm{~cm})$, average diameter of fruit $\left(3.98 \mathrm{~cm}\right.$ )were reported in treatment $\mathrm{T}_{5}$ (drip irrigation with $80 \%$ ETc and fertigation at $100 \%$ RDF) as compared to other treatments. However maximum individual weight of fruit (133.03 gm), number of fruit per plant (34.80), Maximum yield of fruit (132.62tonne/ha) were observed in $\mathrm{T}_{5}$ treatment respectively. Also higher O: I ratio (2.65:1) was observed in $\mathrm{T}_{5}$ treatment and minimum (1.6:1) under $\mathrm{T}_{9}$ treatment. By considering all the aspects treatment $\mathrm{T}_{5}$ was observed best among all other treatments.

\section{Introduction}

Vegetables impart not only nutritional security but also play a main role in economic viability and fit well into predominant intensive cropping system prevailing in different part of our country. More than 60 kinds of vegetables are cultivated in India produced 162.19 million tonnes of vegetables and vegetables export from our country was worth worth₹ 5462.93 crores. Though India's share in global market is only about $1 \%$, there is increasing of horticultural products from our country is necessary. (Anonymous, 2014). Cucumber (Cucumis sativus L) is mostly preferred vegetables from cucurbitaceae family. In our country, Cucumber is cultivated in 71 thousand's ha with production of 1.202 lakh MT and productivity of 16.929 thousand's MT/ha in 2015-16 year (Anonymous, 2017). The nutritive value of $100 \mathrm{~g}$ of edible cucumber is calcium (14 mg), magnesium (15 $\mathrm{mg}$ ), potassium (127 mg), vitamin C (12mg), Niacin $(0.3 \mathrm{~g})$, protein $(0.6 \mathrm{~g})$, dietary fiber 
$(0.5 \mathrm{~g}), \quad$ carbohydrate $\quad(2.2-3.6 \quad \mathrm{mg})$ (Anonymous, 2018). It contains more than 90 $\%$ water content, which making cucumber an ideal hydrating and cooling food. It is a very good source of potassium, vitamin $\mathrm{K}$ and some unique anti-oxidants, which are good for brains, heart and urinary system of human body (Sikarwar and Hardaha, 2016). Generally Cucumber is warm season crop. But due to polyhouse technique it can be grown winter season also for provide more profit to farmers.

In looking at the future scenario, water scarcity is considered as the largest water problem worldwide (Jury and Vaux 2005). It is obvious then that the solution to this problem lies mostly on improving the efficiency of water use for food production. Polyhouse techniques achieves higher water and nutrient use efficiencies (Bhattarai et al., 2015). In polyhouse technique yield of crop increased but proper water and fertiliser management will be necessary.

Fertigation is the application of water soluble solid fertiliser applied through drip irrigation directly to the root zone plant. It increases the fertilizer efficiency by saving fertilizer. In polyhouse technique yield of crop increased but proper water and fertiliser management will be necessary. The present work was conducted to study the effect of irrigation and fertigation levels on growth and yield of cucumber crop under NVP in order to find out best combination of water and fertilizer treatment.

\section{Materials and Methods}

The present research work was conducted inside the naturally ventilated polyhouse during winter season of 2017-18 at plasticulture farm of CTAE, Maharana Pratap University of Agriculture and Technology, Udaipur. Nine treatments combination were applied in Randomized Block Design with three replications. The treatments consist of 3 levels of irrigation. viz. $100 \% \operatorname{ET}_{\mathrm{C}}\left(\mathrm{I}_{1}\right)$, $80 \% \mathrm{ET}_{\mathrm{C}}\left(\mathrm{I}_{2}\right), \quad 60 \% \mathrm{ET}_{\mathrm{C}}\left(\mathrm{I}_{3}\right)$, through drip irrigation and 3 level of fertigation, $125 \%$ $\operatorname{RDF}\left(\mathrm{F}_{1}\right), \quad 100 \% \quad \operatorname{RDF}\left(\mathrm{F}_{2}\right), \quad 75 \% \quad \operatorname{RDF}\left(\mathrm{F}_{3}\right)$ through drip.

\section{Estimation of Reference Crop Evapotranspiration (ETo)}

The daily reference crop evapotranspiration was estimated by using the standard method i.e. FAO Penman-Monteith (Allen et al., 1998)

\section{Crop evapotranspiration}

The daily crop evapotranspiration was estimated using Equation as shown below:

$\mathbf{E T}_{\mathrm{C}}=\mathbf{K}_{\mathrm{C}} \times \mathbf{E T}_{\mathrm{o}}$

Where, $\mathrm{ET}_{\mathrm{c}}=$ crop evapotranspiration, $(\mathrm{mm} /$ day $), \quad \mathrm{K}_{\mathrm{c}}=$ crop coefficient, $\mathrm{ET}_{0}=$ Reference Crop Evapotranspiration, ( $\mathrm{mm} /$ day)

The volume of water required under drip irrigation system was computed by following formula.

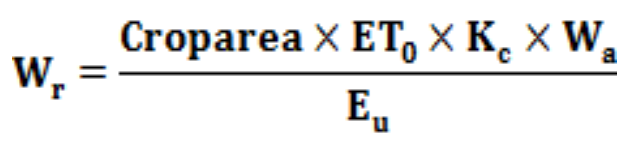

Where, $\mathrm{W}_{\mathrm{r}}=$ peak water requirement, (lit/day/plant), Crop area $=$ row to row spacing (m) $\times$ plant to plant spacing $(\mathrm{m})$ of the crop, $\mathrm{ET}_{0}=$ reference evapotranspiration, ( $\mathrm{mm} /$ day), $\mathrm{K}_{\mathrm{c}}=$ crop coefficient, $\mathrm{Wa}=$ wetted area, $(\%)$.

Mini Angel F1 hybrid cucumber was sown under naturally ventilated polyhouse on $4^{\text {th }}$ Oct 2017 with 2 rows per plot consisting of 64 plants/plot. Keeping row to row, plant to plant distance $50 \mathrm{~cm} \times 50 \mathrm{~cm}$ respectively. Total 27 
lateral was used for experimental set up. Each lateral served one row with in-line emitter distance at $30 \mathrm{~cm}$ and discharge rate of 2 lit per hour.

Irrigation scheduling has been decided before growing of the crop by using the last five year data i.e. 2012-13 to 2016-17 for the months Oct to February. Available capacity of tank was 5000 lit, so for convenient basis, water was supplied after total depletion of 5000 lit water. Mean water was applied with 5 to 7 days interval according to the treatments. Scheduling of fertilizer was done by Full dose of $\mathrm{P}$, half dose of $\mathrm{N}$ and $\mathrm{K}$ applied as basal dose and remaining half dose of $\mathrm{N}, \mathrm{K}$ was applied through fertigation after 30 DAS in 5 day interval into 3 fertigation levels $125 \%$ RDF, $100 \%$ RDF, $75 \%$ RDF.

All other packages, input sources and practices were adopted same to all treatment as recommended for the region.

The water use efficiency was determined by following equation:

$\mathrm{WUE}=\frac{\mathrm{Y}}{\mathrm{WR}}$

Where, WUE = Water Use Efficiency, $\left(\mathrm{kg} / \mathrm{m}^{3}\right), \mathrm{Y}=$ Crop yield, $(\mathrm{kg} / \mathrm{ha}), \mathrm{WR}=$ water requirement, $\left(\mathrm{m}^{3} / \mathrm{ha}\right)$.

The fertilizer use efficiency was computed by the following equation.

$$
\mathrm{UE}=\frac{\text { Crop Yield }\left(\frac{\mathrm{kg}}{\mathrm{ha}}\right)}{\text { Total quantity of nutrient applied }(\mathrm{kg} / \mathrm{ha})}
$$

Statistical analysis of data was performed using a randomized block design with three replication. 5\% level of significance was considered in ANOVA to test the influence of different irrigation and fertigation levels on growth and yield attributes of cucumber.

\section{Results and Discussion}

The performance evaluation of drip irrigation system was studied before conducting the experiment. The drip system performed at emission uniformity of $85.93 \%$ with $1.76 \mathrm{lph}$ average discharge rate indicating the good performance of the system. Physio-chemical properties of soil was also determined.

Actual water required for cucumber crop was determined by penman Monteith equationusing daily climatic data under NVPH during season 2017-18. According to this total 21 times 5000 lit of irrigation water was supplied to crop as per the different treatments i.e. $100 \% \mathrm{ET}_{\mathrm{C}}, 80 \% \mathrm{ET}_{\mathrm{C}}$ and $60 \% \mathrm{ET}_{\mathrm{C}}$. Total water requirement of cucumber crop under $\mathrm{NPVH}$ at $100 \% \mathrm{ET}_{\mathrm{C}}$ (i.e $\mathrm{T}_{1}, \mathrm{~T}_{2}, \mathrm{~T}_{3}$ ), 80 $\% \mathrm{ET}_{\mathrm{C}}$ (i.e. $\mathrm{T}_{3}, \mathrm{~T}_{4}, \mathrm{~T}_{5}$ ) and $60 \% \mathrm{ET}_{\mathrm{C}}$ (i.e $\mathrm{T}_{6}$, $\mathrm{T}_{7}, \mathrm{~T}_{8}$ ) was $269.98 \mathrm{~mm}, 215.98 \mathrm{~mm}$ and $156.93 \mathrm{~mm}$ respectively.

The observations were recorded on WUE, FUE, various growth parameters, yield parameters of cucumber and were subjected to statistical analysis. The results regarding to this are discussed as follows:

\section{Water use efficiency}

Water use efficiency was significantly improved by interactive effect of different irrigation and fertigation level (Fig.1). The result of study indicated that water use efficiency increased by reduction in irrigation water applied through drip with higher level of fertigation. Highest WUE $\left(62.33 \mathrm{~kg} / \mathrm{m}^{3}\right)$ was realized for $\mathrm{T}_{7}$ treatment (drip irrigation with $60 \%$ ETc and fertigation at $125 \%$ RDF) because this treatment consumed less water with higher level of fertigation. Lowest WUE $\left(38.88 \mathrm{~kg} / \mathrm{m}^{3}\right)$ was obtained under $\mathrm{T}_{1}$ treatment (drip irrigation with 60\% ETc and fertigation at $125 \% \mathrm{RDF}$ ) due to more water applied as compare to other treatments. But at 
$\mathrm{T}_{5}$ treatment, WUE $\left(61.40 \mathrm{~kg} / \mathrm{m}^{3}\right)$ was observed with comparatively higher yield. This results are also agreement with (Dunage et al., 2008), (Soni 2013), (Joshi 2014) and (Rajak 2015). (Rahil and Qanadillo (2015) was reported that $70 \% \mathrm{ET}_{\mathrm{C}}$ treatments has higher WUE $\left(33 \mathrm{~kg} / \mathrm{m}^{3}\right)$ of cucumber crop than under $\mathrm{F} 1, \mathrm{~T} 1$ and $\mathrm{ET}_{\mathrm{C}}$ treatments under greenhouse cultivation. (Wang and Xing 2016) researcher reported that in tomato crop highest WUE is obtained in the W3F1 (W3$50 \% \quad \mathrm{ET}_{\mathrm{C}}, \quad \mathrm{F} 1-\mathrm{N}-240-\mathrm{P}_{2} \mathrm{O}_{5} \quad-120-\mathrm{K}_{2} \mathrm{O}-150$ $\mathrm{kg} \cdot \mathrm{ha}^{-1}$ ) treatment in tomato crop and was 45 $\mathrm{kg} \cdot \mathrm{m}^{-3}$ and $47.7 \mathrm{~kg} \cdot \mathrm{m}^{-3}$ in 2012 and 2013, respectively.

\section{Fertilizer use efficiency}

The fertilizer use efficiency as influenced by irrigation and fertilizer levels was depicted in Fig.2. The FUE has decreased with increase in level of fertilizer in all the treatment.

It is seen from the Fig.2 that the highest fertilizer use efficiency recorded was $579.27 \mathrm{~kg}$ of yield $/ \mathrm{kg}$ of nutrients applied in Treatment $\mathrm{T}_{6}$ (drip irrigation with $80 \%$ ETc and fertigation at $75 \% \mathrm{RDF})$. It might be attributed to reduction in quantity of nutrient applied in this treatment and no leaching of nutrients in the form of runoff. Also might be due to efficient use of water $\left(80 \% \mathrm{ET}_{\mathrm{C}}\right)$ increase nutrient uptake by the plant, corresponded with lower fertilizer applied. The researcher (Soni 2013), (Rajak 2015), (Joshi 2014) stated that at Low level of fertigation FUE is higher.

\section{Growth parameters of cucumber crop}

\section{Plant height}

At 30 DAS and 60 DAS, plant height was observed maximum $(133.8 \mathrm{~cm}$ and $295.27 \mathrm{~cm})$ in $\mathrm{T}_{4}$ treatment followed by $\mathrm{T}_{5}$ (130.93 and $295.07 \mathrm{~cm}$ ), which is significantly higher than other 8 treatments and lower with $\mathrm{T}_{9}(104.00$ and $202.53 \mathrm{~cm}$ ) respectively. At 90 DAS and last harvest, plant height was obtained maximum $(381.13 \mathrm{~cm}$ and $399.27 \mathrm{~cm})$ under $\mathrm{T}_{5}$ treatment followed by $\mathrm{T}_{4}(373.00$ and $398.67 \mathrm{~cm}$ ). This might be due to optimum availability of nutrients and moisture. Result showed that there is less significant difference between $\mathrm{T}_{4}$ and $\mathrm{T}_{5}$ treatment. The minimum plant height (253.73 and 271.47) was recorded in $\mathrm{T}_{9}$ treatment at $90 \mathrm{DAS}$ and at last harvest respectively.

Plant height of cucumber reported by Gupta et al., (2014) was $248.41 \mathrm{~cm}(8.15 \mathrm{ft})$ at treatment combination of $80 \%$ ET through drip $+80 \%$ recommended NPK through fertigations. Imamsaheb et al., (2011) revealed that the application of 100 per cent fertilizers through water soluble fertilizer through drip at 80 per cent evaporation resulted in higher plant height $(96.70 \mathrm{~cm})$ in tomato crop.

\section{Days to $50 \%$ flowering and days to first harvest}

Days to $50 \%$ flowering was significantly influenced by effect of irrigation and fertigation level as shown in Table 1 . Minimum days required for $50 \%$ flowering was reported in treatment $\mathrm{T}_{5}$ (30.67) followed by treatment T4 (31.67). Maximum days required for $50 \%$ flowering was reported in $\mathrm{T}_{9}$ (36.67).Treatment $\mathrm{T}_{9}$ (drip irrigation with $60 \%$ ETc and fertigation at $75 \%$ RDF) prolonged the vegetative growth so that late flowering occurred at $\mathrm{T}_{9}$.

Minimum days required for first harvest was reported in treatment $\mathrm{T}_{5}(42.67)$ at par with treatment $\mathrm{T}_{4}(43.33)$ and superior to all other treatments. This might be due to very favorable combination of irrigation $\left(80 \% \mathrm{ET}_{\mathrm{C}}\right)$ and fertigation level (100\% RDF of NPK). Maximum days required for first harvest was reported in $\mathrm{T}_{9}$ (48.33). 
Table.1 Effect of different irrigation and fertigation levels on growth Parameter of cucumber plant

\begin{tabular}{|c|c|c|c|c|c|c|c|c|c|}
\hline \multirow{2}{*}{\multicolumn{2}{|c|}{ Treatment }} & \multicolumn{4}{|c|}{ Plant height (cm) } & \multirow{2}{*}{$\begin{array}{l}\text { Days for } \\
50 \% \\
\text { flowering }\end{array}$} & \multirow{2}{*}{$\begin{array}{l}\text { Days to } \\
\text { first } \\
\text { harvest }\end{array}$} & \multirow{2}{*}{$\begin{array}{l}\text { Length } \\
\text { of fruit } \\
(\mathrm{cm})\end{array}$} & \multirow{2}{*}{$\begin{array}{l}\text { Dia. } \\
\text { of } \\
\text { fruit } \\
\text { (cm) }\end{array}$} \\
\hline & & $\begin{array}{c}30 \\
\text { DAS }\end{array}$ & $\begin{array}{c}60 \\
\text { DAS }\end{array}$ & $90 \mathrm{DAS}$ & $\begin{array}{c}\text { At } \\
\text { harvest }\end{array}$ & & & & \\
\hline $\mathbf{T}_{1}$ & $\mathrm{I}_{1} \mathrm{~F}_{1}$ & 124.00 & 259.73 & 324.00 & 339.93 & 32 & 44.67 & 14.12 & 3.42 \\
\hline $\mathbf{T}_{2}$ & $\mathrm{I}_{1} \mathrm{~F}_{2}$ & 128.20 & 272.60 & 340.27 & 357.87 & 31.67 & 45.33 & 14.37 & 3.51 \\
\hline$\overline{T_{3}}$ & $\mathrm{I}_{1} \mathrm{~F}_{3}$ & 118.00 & 249.93 & 322.33 & 338.27 & 34.33 & 47.00 & 13.55 & 3.35 \\
\hline $\mathbf{T}_{4}$ & $\mathrm{I}_{2} \mathrm{~F}_{1}$ & 133.80 & 295.27 & 373.00 & 398.67 & 31.67 & 43.33 & 14.77 & 3.68 \\
\hline $\mathbf{T}_{5}$ & $\mathrm{I}_{2} \mathrm{~F}_{2}$ & 130.93 & 295.07 & 381.13 & 399.27 & 30.67 & 42.67 & 15.92 & 3.98 \\
\hline$\overline{T_{6}}$ & $\mathrm{I}_{2} \mathrm{~F}_{3}$ & 117.80 & 233.87 & 305.27 & 322.20 & 34.33 & 46.67 & 13.00 & 3.42 \\
\hline $\mathbf{T}_{7}$ & $\mathrm{I}_{3} \mathrm{~F}_{1}$ & 113.00 & 223.73 & 285.20 & 303.80 & 35.33 & 46.67 & 12.15 & 3.11 \\
\hline $\mathbf{T}_{8}$ & $\mathrm{I}_{3} \mathrm{~F}_{2}$ & 113.53 & 219.47 & 272.40 & 289.93 & 36.00 & 48.00 & 12.87 & 3.06 \\
\hline$T_{9}$ & $\mathrm{I}_{3} \mathrm{~F}_{3}$ & 104.00 & 202.53 & 253.73 & 271.47 & 36.67 & 48.33 & 12.09 & 3.00 \\
\hline & & 4.88 & 6.83 & 8.78 & 8.81 & 0.48 & 0.46 & 0.23 & 0.07 \\
\hline & at 5 & 14.63 & 20.49 & 26.3 & 26.43 & 1.44 & 1.38 & 0.69 & 0.22 \\
\hline
\end{tabular}

Table.2 Effect of different irrigation and fertigation levels on yield attributes of cucumber plant

\begin{tabular}{|c|c|c|c|c|c|c|c|}
\hline \multicolumn{2}{|c|}{ Treatment } & $\begin{array}{l}\text { Individual } \\
\text { weight of fruit } \\
\text { (gm) }\end{array}$ & $\begin{array}{l}\text { No. of } \\
\text { fruit per } \\
\text { plant }\end{array}$ & $\begin{array}{l}\text { Weight of } \\
\text { fruits / plant } \\
\text { (kg) }\end{array}$ & $\begin{array}{l}\text { Yield / } \\
\text { plot (kg) }\end{array}$ & $\begin{array}{l}\text { Yield / } \\
\text { sq.m } \\
\text { Kg/sq. } \\
\text { m }\end{array}$ & $\begin{array}{l}\text { Yield } \\
\text { (ton/ha) }\end{array}$ \\
\hline $\mathbf{T}_{1}$ & $\mathrm{I}_{1} \mathrm{~F}_{1}$ & 105.73 & 30.13 & 2.62 & 167.96 & 10.5 & 104.972 \\
\hline$\overline{T_{2}}$ & $\mathrm{I}_{1} \mathrm{~F}_{2}$ & 109.91 & 30.00 & 2.88 & 184.33 & 11.52 & 115.21 \\
\hline $\mathbf{T}_{3}$ & $\mathrm{I}_{1} \mathrm{~F}_{3}$ & 88.94 & 29.67 & 2.71 & 173.39 & 10.84 & 108.37 \\
\hline $\mathrm{T}_{4}$ & $\mathrm{I}_{2} \mathrm{~F}_{1}$ & 113.95 & 31.67 & 2.99 & 191.09 & 11.94 & 119.43 \\
\hline$\overline{T_{5}}$ & $\mathrm{I}_{2} \mathrm{~F}_{2}$ & 133.03 & 34.80 & 3.32 & 212.20 & 13.26 & 132.62 \\
\hline $\mathrm{T}_{6}$ & $\mathrm{I}_{2} \mathrm{~F}_{3}$ & 86.46 & 28.40 & 2.72 & 173.78 & 10.86 & 108.61 \\
\hline$\overline{T_{7}}$ & $\mathrm{I}_{3} \mathrm{~F}_{1}$ & 76.37 & 28.13 & 2.52 & 161.56 & 10.10 & 100.97 \\
\hline $\mathbf{T}_{8}$ & $\mathrm{I}_{3} \mathrm{~F}_{2}$ & 76.45 & 27.33 & 2.34 & 149.57 & 9.35 & 93.48 \\
\hline $\mathrm{T}_{9}$ & $\mathrm{I}_{3} \mathrm{~F}_{3}$ & 74.07 & 24.93 & 2.00 & 127.88 & 7.99 & 79.92 \\
\hline \multicolumn{2}{|c|}{ SEm \pm} & 5.18 & 1.86 & 0.08 & 14.11 & 0.88 & 8.82 \\
\hline \multicolumn{2}{|c|}{ CD at 5} & 15.54 & 5.58 & 0.25 & 42.29 & 2.64 & 26.43 \\
\hline
\end{tabular}


Fig.1 Water use efficiency (WUE) of cucumber in different treatments

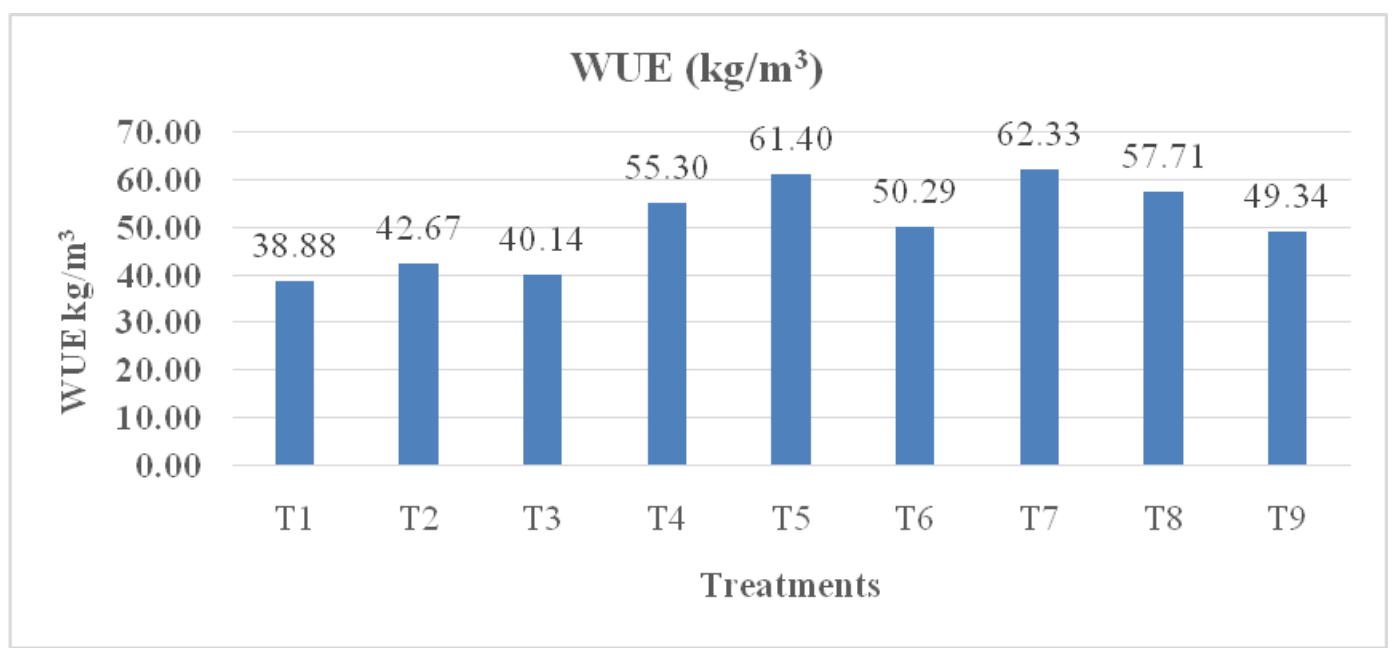

Fig.2 Fertilizer use efficiency (FUE) of cucumber in different treatments

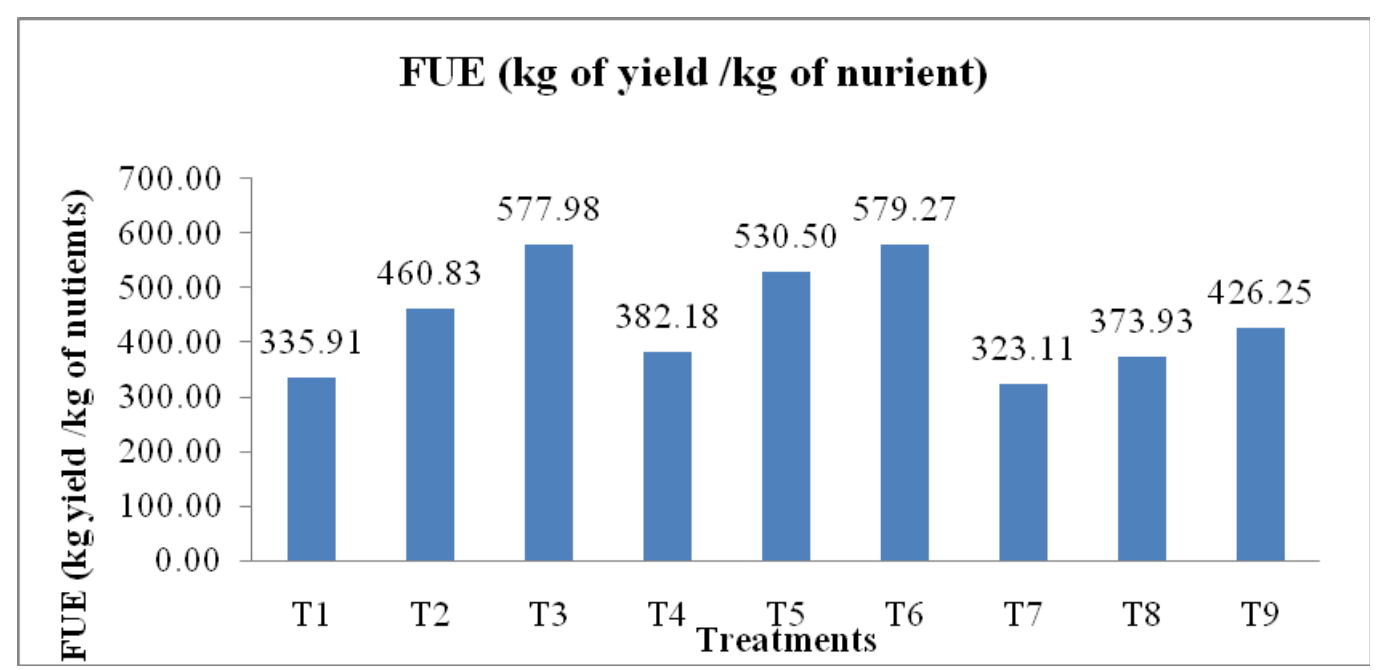

It might be attributed to low level of drip irrigation with low level of fertigation. It prolongs the vegetative growth of cucumber plant and delayed maturity.

\section{Length and diameter of cucumber}

Maximum average length of fruit and average diameter of the fruit were reported in treatment $\mathrm{T}_{5}$ (drip irrigation with $80 \% \mathrm{ETc}$ and fertigation at $100 \% \mathrm{RDF})$ i.e. $15.92 \mathrm{~cm}$ and 3.98 cmand followed by $\mathrm{T}_{4}(14.77 \mathrm{~cm}$ and $3.68 \mathrm{~cm}$ ) respectively (Table.2). Minimum length of fruit and diameter of fruit was reported in $\mathrm{T}_{9}(12.09 \mathrm{~cm}$ and $3.00 \mathrm{~cm})$ respectively. It might be due to optimum availability of water and nutrient without loss of fertiliser increases photosynthesis. Also might be due to higher nutrient uptake by plant at drip irrigation with $80 \%$ ETc and fertigation at $100 \%$ RDF. Patil and Gadge (2016) reported the maximum average diameter of the cucumber fruit was observed with application of 100 per cent $\mathrm{N}$ through drip and soil application of $\mathrm{P}$ and $\mathrm{K}$ i.e. T2 $(3.89 \mathrm{~cm})$. Also Gao et al., (2016) found that $90 \%$ of field capacity was a highest diameter of cucumber fruit. 


\section{Yield parameter}

\section{Individual fruit weight}

The data regarding to individual weight of fruit are presented in Table.2. Individual weight of fruit was affected significantly due to combined effect of irrigation and fertigation levels. The fruit weight plays an important role in increasing the total yield in cucumber. However, the individual fruit weight (133.03 gm) was recorded in treatment $\mathrm{T}_{5}$ followed by $\mathrm{T}_{4}(113.95 \mathrm{gm})$ which was significantly superior over the all other treatments. This was largely due to the increased length and diameter of fruit. This could be due to a high uptake of nutrients and build-up of sufficient photosynthesis enabling the increase in size of fruits (length and diameter), resulting in the increased fruit weight and its volume. The lowest individual fruit weight $(74.07 \mathrm{gm})$ was recorded in treatment $\mathrm{T}_{9}$.

\section{No. of fruits per plant}

Maximum no. of fruit per plant was obtained in $\mathrm{T}_{5}$ (34.80) followed by $\mathrm{T}_{4}$ treatment (31.67). This result shown that at $80 \% \mathrm{ET}_{\mathrm{C}}$ with $100 \%$ and $125 \%$ RDF of NPK due to favourable condition more aeration, sufficient moisture and high uptake of nutrient as compared to other treatment, enhanced vegetative growth. Plant height obtained in T5 was higher means higher no. of nodes resulting in higher no. of fruit. Minimum no. of fruit per plant (24.93) was obtained in $\mathrm{T}_{9}$. Due to inadequate water and low level of fertigation, less plant height. Gupta et al., (2014) reported that in cucumber crop maximum no. of fruit (22) was obtained in treatment combination of $80 \%$ ET through drip $+80 \%$ recommended NPK through fertigations. Also by Imamsaheb et al., (2011)revealed that the application of 100 per cent fertilizers through water soluble fertilizer through drip at 80 per cent evaporation in tomato crop resulted in significantly higher number of fruits per plant (40.71).

\section{Yield of fruit}

The data pertaining to average total weight of fruits per plant and yield of crop as influenced by different irrigation and fertigation levels are presented in Table 4.18. Fruits weight per plant, fruit yield per plant, fruit yield per square meter area and fruit yield per hectare (ton/ha) is represented in Fig. 4.12 Fig. 4.13, Fig. 4.14 and Fig. 4.15 respectively. Maximum weight of fruit per plant, Yield per plot $\mathrm{kg}$, yield per sq.mwere observed in $\mathrm{T}_{5}$ treatment $(3.32 \mathrm{~kg}), \quad(212.20 \mathrm{~kg} / \mathrm{plot})$, (13.26kg/sq.m), respectively. Minimum weight of fruit per plant, Yield per plot $(\mathrm{kg})$, yield per sq.m, were observed in $\mathrm{T}_{9}$ treatment $(2.00 \mathrm{~kg}),(127.80 \mathrm{~kg} / \mathrm{plot}), \quad(7.99 \mathrm{~kg} / \mathrm{sq} \cdot \mathrm{m})$ respectively.

Table 4.18 shown that maximum yield of cucumber per hectare was obtained in T5 treatment (132.62 tonnes per ha) followed by T4 treatment (119.43 tonnes per ha). This result might be due to maximum no. of plant, higher individual weight of fruit obtained in T5 treatment. This might be attributed due to favourable combination of moisture and nutrient available to crop enhanced vegetative and yield growth. Lower yield (79.92 tonnes per ha) was recorded in T9 treatments due to lesser uptake of nutrient by the crop under low level of irrigation and fertigation level. Gupta et al., (2014) reported that treatment combination of $80 \%$ ET through the drip + $80 \%$ RDF of NPK through fertigation produced maximum yield 144.41 tonne/ha.

The result of study showed that combination of different irrigation and fertigation levels have significant effect on WUE, FUE, growth and yield attributes of cucumber. The result concluded that WUE increased with reduction 
in water applied and FUE was enhanced with decreasing quantity of fertilizer applied. There is no significant relation between yield and WUE.

Vegetative growth, was enhanced Due to sufficient moisture availability and higher nutrient uptake by the plant, so increases photosynthesis and cell resulted into more yield. This study concluded that $80 \%$ ETc significantly increases cucumber yield than $100 \%$ ETc at 100\% RDF fertigation. By considering all the aspects such as growth and yield parameters, in water scarcity area, treatment $\mathrm{T}_{5}$ (drip irrigation with $80 \%$ ETc and fertigation at $100 \% \mathrm{RDF}$ ) is best among all other treatments for cucumber crop under naturally ventilated polyhouse in off season in order to get maximum profit.

\section{References}

Allen, R.G., Pereira, L.S., Raes, D. and Smith, M. $1998 . \quad$ Crop evapotranspiration guidelines for computing crop water requirements. Irrigation and Drain, Paper no. 56. FAO, Rome.

Anonymous, 2014. Indian Council of Agricultural research icar.org.in/en/node/7847visited on 5.09.2017.

Anonymous, 2018. Nutritional recommendations for cucumber in open fields, tunnels and greenhouse. http://www.haifagroup.com/files/Guides/Cucumber.pdf

Anonymous. 2017. National horticulture board. Horticulture Crops Estimates for the Year 2016-17 http://nhb.gov.in/statistics/State_Level/2 016-17(Final).pdf

Bhattarai, P., Kaushik, R.A., Ameta, K.D., Jain, H.K., Kaushik, M.K. and Sharma, F.L. 2015 Effect of plant geometry and fertigation on growth and yield of cherry tomato (Solanum lycopersicon var. cerasiforme) under zero energy polyhouse conditions Indian J. Hort. 72: 297-301.

Dunage, V.S., Balakrishnan, P. and Patil, M.G. 2008. Water use efficiency and economics of tomato using drip irrigation under nethouse conditions. Karnataka Journal of Agriculture Science. 22: 133-136.

Gao, N., Liu, Y., Wu, H., Zhang, P., Yu, N., Zhang, Y., Zou, H., Fan, Q. and Zhang, Y. 2016. Interactive effects of irrigation and nitrogen fertilizer on yield, nitrogen uptake, and recovery of two successive Chinese cabbagecrops as assessed using $15^{\mathrm{N}}$ isotope Scientia Horticulturae 215: $117-125$

Gupta, A.J., Chattoo, M.A. and Bhat F.N. 2014. Standardization of drip irrigation and fertigation practices for commercial cultivation of hybrid cucumber under Kashmir conditions. Progressive Horticulture. 46: 343-348.

Imamsahab, S.J., Patil, M.G., Naik, M.K., Hussain, Abbas, S. and Ayyangoudar, M.S. 2011. Yield, yield components and qualityof processing tomato (Solanum $\begin{array}{lll}\text { lycopersicum } & \text { L.) } & \text { genotypes }\end{array}$ asinfluenced by different levels of fertigation. Environ. \& Ecol., 29: 229232.

Joshi, Y.K. 2014. Study of gravity fed drip irrigation system with varied irrigation and fertigation levels in okra. M.Tech thesis submitted to Maharana Pratap University of Agriculture and Technology Udaipur (Rajasthan).

Jury, W.A. and Vaux, H.J. 2005. The role of science in solving the world's emerging water problems. Proc.Natl.Acad.Sci.102:15715-15720.

Patil, M. and Gadge, S. B. (2016). Yield response of cucumber (Cucumis sativus L.) to different fertigation levels. Internat. J. Agric. Engg., 9: 145-149. 
Rahil, M.H. and Qanadillo, A. 2015. Effects of different irrigation regimes on yield and water use efficiencyof cucumber crop. Agricultural Water Management, 148: $10-15$

Rajak, D. 2015. Studies on the effect of irrigation and fertigation level on cabbage under gravity fed drip irrigation. Ph.D. thesis submitted to Maharana Pratap University of Agriculture and Technology Udaipur (Rajasthan).

Sikarwar, P. and Hardaha, M.K. 2016. Effect of fertigation levels on growth, quality and yield of polyhouse cucumber
(Cucumis sativus). International Journal of Agriculture Sciences 8: 1863-1866.

Soni, K. 2013.A study on drip irrigation and fertigation of tomato (Lycopersicon esculentum) crop inch hindwara district of (M.P.). M. Tech thesis submitted to the Jawaharlal Nehru Krishi Vishwa Vidyalaya, Jabalpur.

Wang, X. and Xing Y. 2016. Evaluation of the Effect of Irrigation and Fertilization by Drip Fertigation on Tomato Yield and Water Use Efficiency in Greenhouse International Journal of Agronomy: 1-10.

\section{How to cite this article:}

Dattatray P. Pawar, S. R. Bhakar, S. S. Lakhawat, Mahesh Kothari and Vinay Patil. 2018. Interactive Impact of Irrigation and Fertigation Level on Growth and Yield Attributes of Cucumber under Naturally Ventilated Polyhouse. Int.J.Curr.Microbiol.App.Sci. 7(06): 26042612. doi: https://doi.org/10.20546/ijcmas.2018.706.308 